\title{
EFEK PEMBERIAN ALPHA LIPOIC ACID PADA ENDOTEL TIKUS PUTIH YANG DIINDUKSI LIPOPOLISAKARIDA
}

\author{
Olvie Syenni Datu' ${ }^{1)}$, Fransisco P Sumalong2) \\ 1)Program Studi Farmasi FMIPA UNSRAT Manado, 95115 \\ 2)Instalasi Farmasi, Dinas Kesehatan Provinsi SULUT Manado,
}

\begin{abstract}
Endothelial dysfunction play a major role in the pathogenesis of vascular diseases, especially atherosclerosis. Endothelial dysfunction causes endothelial cells are activated and resulting homeostasis changes in endothelial cell. Rats were induced by LPS $0.5 \mathrm{mg} / \mathrm{kg}$ and treated with ALA at doses of $30 \mathrm{mg} / \mathrm{kg}, 60 \mathrm{mg} / \mathrm{kg}$ and $120 \mathrm{mg} / \mathrm{kg} \mathrm{BW}$ for 2 weeks which given 1 hour before the LPS administration. This study show that LPS causes morphological changes in rat aorta based on histochemical staining show that endothelial cell are irregular, not homogeneous and increase permeability but in group that received show that ALA can improve the morphological of endothelial cell by reduces ROS, regenerates of exogenous and endogenous antioxidants. Administration of ALA and LPS reduce the rats body weight but not significant compared to the control group. Therefore can be concluded that administration of ALA can prevent endothelial dysfunction.
\end{abstract}

Keywords: Endothel dysfunction, alpha lipoic acid, lipopolysaccharide

\begin{abstract}
ABSTRAK
Disfungsi endotel berperan penting pada pathogenesis penyakit vascular, khususnya aterosklerosis. Disfungsi endotel menyebabkan sel endotel teraktivasi dan terjadi perubahan homeostatis pada sel endotel. Tikus diinduksi dengan LPS $0.5 \mathrm{mg} / \mathrm{Kg}$ BB dan selanjutnya di terapi dengan ALA pada dosis $30 \mathrm{mg} / \mathrm{Kg} \mathrm{BB}, 60 \mathrm{mg} / \mathrm{Kg} \mathrm{BB}$, dan $120 \mathrm{mg} / \mathrm{Kg}$ BB selama 2 minggu 1 jam sebelum pemerian LPS. Penelitian ini menujukan bahwa LPS dapat menyebabkan perubahan morfologi pada sel nedotel berdasakan pada hasil pewarnaan jaringan yang menunjukan sel endotel yang tersusun tidak beraturan, tidak homogeny dan terjadi peningkatan permeabilitas tapi pada kelompok perlakuan yang mendapatkan terapi ALA menunjukan ALA dapat memperbaiki morfologi sel endotel dengan mengurangi ROS, meningkatkan antioksidan eksogen dan endogen. Pemberian ALA dan LPS tidak menyebabkan perubahan berat badan tikus yang signifikan di bandingkan dengan kelompok control. Sehingga dapat disimpulkan pemberian ALA dapat mencegah disfungsi endotel.
\end{abstract}

Kata Kunci: disfungsi endotel, histokimia, alpha lipoic acid, lipopolisakarida 


\section{PENDAHULUAN}

Penyakit Kardiovaskular merupakan penyakit yang menyebabkan $\pm 36 \%$ dari total kematian di Indonesia. Berdasarkan laporan WHO pada tahun 2008 ada tujuh ratus lima ribu orang yang meninggal karena penyakit kardiovaskular (WHO, 2011).

Penyebab utama dari penyakit ini adalah aterosklerosis ( $\mathrm{Li}$ et al, 2009). Aterosklerosis merupakan penyakit inflamasi kronis yang ditandai dengan penurunan ketebalan arteri secara berangsur-angsur, penyempitan dan pengurangan suplai darah (Xu et al, 2013).

Tahap awal pada patogenesis penyakit kardiovaskular adalah disfungsi endotel. Sel endotel merupakan barier yang memisahkan trombosit dan protein-protein koagulasi, dari komponen-komponen trombogenik yang terdapat pada jaringan sub endotel (Lee et al, 2012)

Sel Endotel berfungsi sebagai regulator lokal aliran darah yaitu dengan menghasilkan senyawa-senyawa vasoaktif seperti endothelial derived relaxation factor (EDRF) dan prostaglandin prostacyclin (PGI2) (Caterina dkk, 2007) Aktivasi faktor transkripsi Nuclear Factor Kappa $\beta$ (NF-кB) dan overproduksi reactive oxigen species (ROS) berkontribusi pada proses inflamasi pada sel endotel (Caterina et al, 2007., Liu et al, 2012).

Disfungsi endotel merupakan lesi aterosklerotik dini, dimana terjadi respon inflamasi yang merubah homeostatis sel endotel, peningkatan permeabilitas sel endotel yang menyebabkan terjadinya migrasi leukosit pada intima dan adesivitas terhadap lipoprotein, leukosit, platelet dan kandungan plasma lain (Ribeiro et al, 2009).

Paparan LPS pada sel endotel baik secara in vivo dan in vitro menyebabkan aktivasi pada sel endotel. Penelitian yang menggunakan model hewan coba menunjukan paparan LPS dapat meningkatkan lesi aterosklerosis ( $\mathrm{Li}$ et al, 2009). LPS akan berikatan dengan reseptor dan mengaktifkan signaling intraselular termasuk NF- $\kappa \mathrm{B}$ dan pembentukan ROS (Wang et al, 2000)

Salah satu terapi yang efektif mengatasi permasalahan stres oksidatif adalah penggunaan antioksidan, ada beberapa Antioksidan yang telah uji berpotensi pada pengobatan disfungsi endotel seperti vitamin $\mathrm{C}$ dan vitamin $\mathrm{E}$.

Alpha lipoic acid (ALA) atau 1,2dithiolane-3-pentanoic acid, yang adalah komponen dithiol yang terbentuk secara alami melalui mekanisme enzimatis pada mitokondria dari asam oktanoid. ALA adalah salh satu antioksidan kuat. ALA adalah kofaktor yang diperlukan untuk mitochondrial $\alpha$-ketoacid dehydrogenasel reaksi bioenergetik mitokondria dan dengan demikian berperan penting pada metabolisme energi pada mitokondria (Shay et al, 2009).

\section{METODOLOGI PENELITIAN}

\section{Waktu dan Tempat Penelitian}

Peneltian ini dilakukan di laboratorium Departemen Farmasi Klinik, Fakultas Farmasi Universitas Airlangga dan Laboratorium Patologi Anatomi RSUD dr. Soetomo, Penelitian ini dilakukan dari Bulan Februari-April 2015.

\section{Alat dan Bahan}

a. Alat

Timbangan tikus, Preparat untuk mikroanatomi : Disecting kit, staining jar, mikrotom, waterbath, objek glas, dek glas, penjepit kayu, mikroskop, kamera.

\section{b. Bahan}

Hewan percobaan, Alpha-lipoic acid (ALA) (Dexa Medica), Pakan hewan uji 
pBR-II (Comfeed), $\mathrm{NaCl}$ 0,9\% (Widatra), Aquadestilata (PT. Brataco), Eter (PT. Brataco), CMC Na 0,1\% (PT. Brataco), Lipopolisakarida Escherichia coli (SigmaAldrich), Hematoksilin-Eosin

\section{Pembuatan model hewan coba terinduksi LPS}

LPS dibuat dengan melarutkan $5 \mathrm{mg}$ LPS kedalam $100 \mathrm{~mL} \quad \mathrm{NaCl} \quad 0,9 \%$ sehingga diperoleh konsentrasi 0,05 mg/mL. LPS $2 \mathrm{~mL}$ disuntikan secara intraperitoneal (IP) pada hewan coba kelompok II-V, sedangkan hewan coba kelompok I sebagai kelompok kontrol disuntik dengan $\mathrm{NaCl}$ 0,9\%. Dosis LPS yang disuntikan adalah $0,5 \mathrm{mg} / \mathrm{kg}$ BB di suntikan 3 kali setiap 3 hari pada minggu pertama penelitian (Zhao et al, 2014., Lee et al, 2012).

\section{Pembuatan dan Pemberiaan sediaan uji} ALA

Dosis yang digunakan pada penelitian ini adalah $30 \mathrm{mg} / \mathrm{kg}$ BB, $60 \mathrm{mg} / \mathrm{kg}$ BB dan 120 $\mathrm{mg} / \mathrm{kg}$ BB. Sediaan uji dengan dosis 25 $\mathrm{mg} / \mathrm{kg} \mathrm{BB}$ dibuat dengan mensuspensikan ALA sejumlah $300 \mathrm{mg}$ ke dalam $100 \mathrm{~mL}$ NaCMC 0,1\%, untuk dosis $60 \mathrm{mg} / \mathrm{kg} \mathrm{BB}$ dibuat dengan mensuspensikan ALA sejumlah $600 \mathrm{mg}$ ke dalam $100 \mathrm{~mL}$ NaCMC $0,1 \%$ dan untuk dosis $120 \mathrm{mg} / \mathrm{kg}$ BB dibuat dengan mensuspensikan ALA sejumlah 1,2 g ke dalam $100 \mathrm{~mL}$ NaCMC 0,1\%.

Pemberiaan sediaan uji dilakukan secara p.o dengan menggunakan sonde, pemberian disesuaikan dengan berat badan masingmasing tikus. Sediaan uji diberikan 1 jam sebelum induksi LPS dan selanjutnya diberikan setiap hari selama 14 hari. Untuk kontrol negatif, diberikan NaCMC $0,1 \%$ sebanyak $2 \mathrm{~mL} /$ tikus setiap hari.

\section{Pembuatan Preparat Slide}

Cara pembuatan preparat jaringan aorta a. Jaringan Aorta diambil, kemudian difiksasi dalam neutral buffered formalin 10\%. Formalin diserap cukup baik oleh jaringan dalam waktu relatif lama yaitu 1-4 jam.

b. Setelah itu jaringan dicuci dengan xylene, direndam dalam parafin dan dipotong.

c. Jaringan aorta tikus yang telah diberi parafin dipotong dengan mikrotome setebal 3-5 $\mu \mathrm{m}$ dan diletakan pada objek glass.

d. Selanjutnya aorta tikus dilakukan pewarnaan dengan menggunakan pewarna jaringan Hematoksilin-Eosin

\section{Analisis Data}

Data Berat badan di analisis dengan menggunakan Indendepent $T$ test dan Anova Two Way.

\section{HASIL DAN PEMBAHASAN}

Dalam Penelitian ini digunakan 30 ekor tikus jantan strain wistar berumur 2-3 bulan dan dibagi menajdi 5 kelompok, masingmasing kelompok terdiri dari 6 ekor tikus. Empat (4) kelompok tikus terdiri dari tiga kelompok perlakuan yaitu tikus yang diinduksi dengan LPS $0,5 \mathrm{mg} / \mathrm{kg}$ BB dan diterapi dengan Alpha lipoic acid dengan 3 dosis yang berbeda yaitu $(30 \mathrm{mg} / \mathrm{kg} \mathrm{BB}, 60$ $\mathrm{mg} / \mathrm{kg} \mathrm{BB}, 120 \mathrm{mg} / \mathrm{kg} \mathrm{BB}$ ), sedangkan satu kelompok lainnya merupakan kelompok kontrol yang diinjeksi dengan $\mathrm{NaCl} 0,9 \%$ dan selanjutnya diberi larutan Propilenglikol.

Setiap kelompok menerima perlakuan selama 14 hari, Hewan diinduksi dengan LPS pada hari ke-1, hari ke-3, hari ke-7 dan pada hari ke 15 hewan di korbankan dan dilakukan pengambilan jaringan aorta. Parameter yang diamati pada penelitian ini adalah berat badan tikus, Histologi jaringan aorta.

a. Berat Badan Tikus

Pemberian LPS 0,5 mg/kg BB pada tikus bertujuan untuk menyebabkan keadaan 
disfungsi endotel. Selama 14 hari penelitian berat tikus coba selalu di pantau, perkembangan berat badan tikus dapat dilihat pada grafik perubahanya dapat dilihat pada Gambar 1

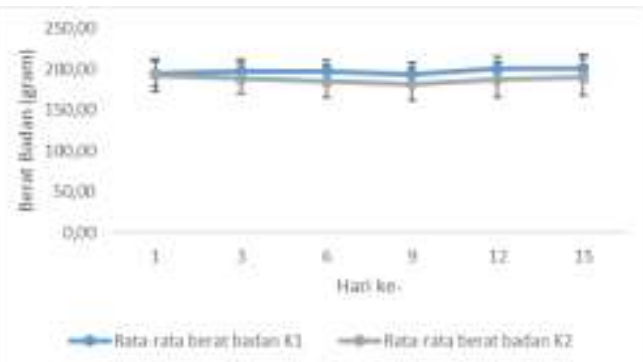

Gambar I. Grafik Perubahan BB tikus normal dan tikus terinduksi LPS

Berdasarkan uji statistik independent $t$ test antara kelompok tikus sehat dan tikus disfungsi endotel secara statistik tidak ada perbedaan bermakna pada perkembangan berat badan tikus baik pada hari 1 sampai pada hari ke 15 , dimana nilai $\mathrm{P}=0,310 \geq 0,05$. Hal ini menunjukan pada pemberian LPS 0,5 $\mathrm{mg} / \mathrm{kg}$ BB tidak menyebabkan perubahan pada berat badan tikus disfungsi endotel.

Pada kelompok perlakuan Berdasarkan uji statistik Anova two way antara kelompok tikus perlakuan I, perlakuan II dan perlakuan III secara statistik tidak ada perbedaan bermakna pada perkembangan berat badan tikus baik pada hari 1 sampai pada hari ke 15 , dimana nilai $\mathrm{P} \geq 0,05$. Hal ini menunjukan pada pemberian LPS $0,5 \mathrm{mg} / \mathrm{kg}$ BB dan ALA dosis $30-120 \mathrm{mg} / \mathrm{kg}$ BB tidak menyebabkan perubahan pada berat badan tikus disfungsi endotel.

b. Histologi Jaringan aorta

Endotel adalah selapis sel yang melapisi seluruh pembuluh darah. Sel endotel berperan penting dalam menjaga hemostasis, permeabilitas pembuluh darah dan respon pembuluh darah pada keadaan fisiologi dan patologis. Pemberian LPS pada tikus akan mempengaruhi morfologi dari endotel.

Gambaran perubahan morfologi pada endotel setelah diinjeksi dengan LPS dipreparasi secara histokimia dengan pewarnaan hematoxylin-eosin (HE).

Pada Gambar 2 dapat diamati irisan melintang Aorta tikus sehat (Gambar A) terlihat sel-sel dengan bentuk memanjang, bentuk dan ukuran sel homogen, tunika intima dan tunika media tampak berbatasan dengan jelas dan rapat sehingga jaringan lebih terlihat dengan jelas (tanda $\longmapsto$ ).

Sedangkan pada aorta tikus disfungsi endotel (gambar B) dapat diamati setelah diinduksi dengan LPS, sel endotel terlihat tidak beraturan, tidak homogen, terjadi peningkatan permeabilitas pada endotel dan susunan pada tunika intima dan media terlihat lebih longgar dan tidak beraturan (tanda
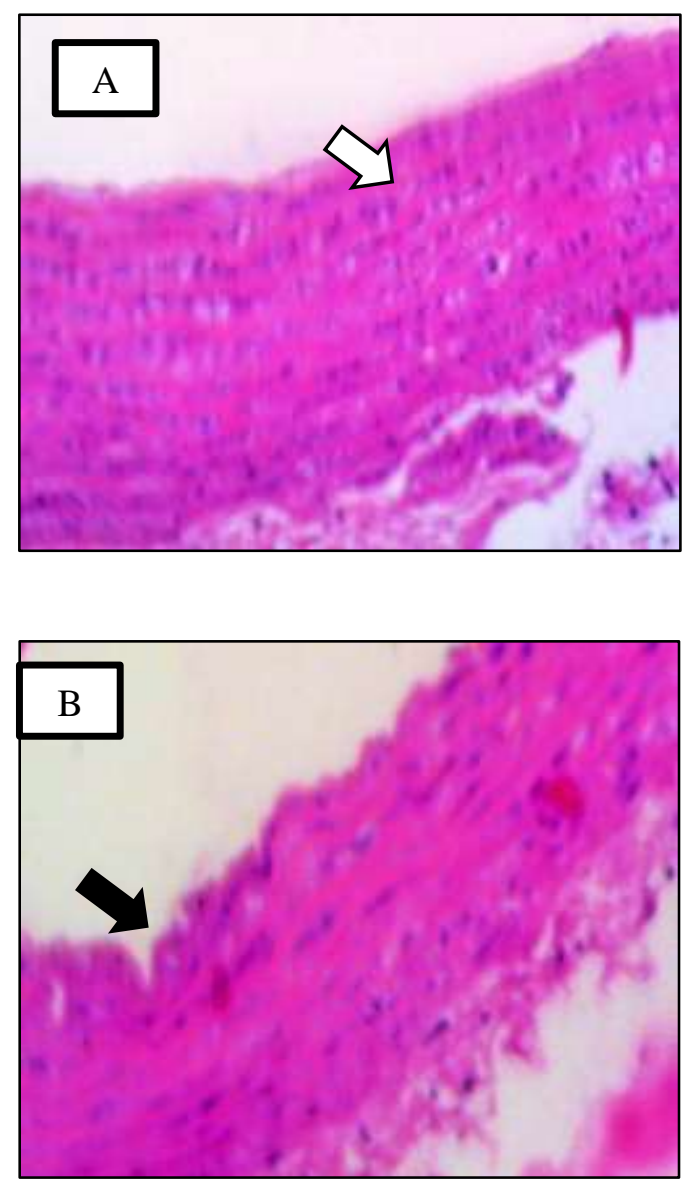
Gambar 2. Irisan melintang jaringan Aorta tikus dengan pewarnaan HE. Aorta tikus sehat ditunjukan oleh gambar A (perbesaran 400x) dan Aorta tikus disfungsi endotel ditunjukan pada gambar B (perbesaran 400x).

Sedangkan pada kelompok Perlakuan I, II, dan III setelah pemberian ALA selama 14 hari menunjukan sel-sel yang tampak homogen dan susunan pada tunika intima dan media terlihat lebih rapat dan dan beraturan.

Hal ini menunukan bahwa ALA yang bersifat antioksidan dapat menstabilkan radikal bebas dengan melengkapi kekurangan elektron yang dimiliki radikal bebas dan menghambat terjadinya reaksi berantai dari pembentukan radikal bebas yang dapat menimbulkan stres oksidatif (Bourassa dan Tardif, 2006).

ALA memiliki kemampuan untuk menghambat kerusakan pada beberapa jaringan termasuk otak, retina dan ginjal. Pada penelitian ini menujukan bahwa ALA memiliki efek perlindungan melawan iskemia/ reperfusi yang diinduksi stress oksidatif (Wang et al, 2011). ALA digunakan secara luas sebagai obat untuk pencegahan berbagai penyakit kronis yang berhubungan dengan stres oksidatif dan pemberian setiap hari bertujuan sebagai antiaging, antidiabetes dan penyakit kardiovaskular (Kofuji et al, 2008).

\section{KESIMPULAN}

Pemberian LPS dapat menimbulkan perubahan pada morfologi sel endotel dan Pemberian ALA dosis $30 \mathrm{mg} / \mathrm{Kg}$ BB, $60 \mathrm{mg} / \mathrm{Kg}$ BB dan $120 \mathrm{mg} / \mathrm{Kg}$ BB dapat memberikan efek proteksif pada endotel.

\section{SARAN}

Perlu dilakukan penelitian lebih lanjut mengenai efek ALA pada disfungsi endotel dengan menggunakan parameter spesifik disfungsi endotel

\section{DAFTAR PUSTAKA}

Bourassa, G., Tardif, C. 2006. Antioxidants and Cardiovascular Disease Second Edition. Springer. Amerika

Caterina, R., Peter, L., Michael, G. 2007. Endothelial Dysfunctions and Vascular Disease. Blackwell Publishing, USA.

Kofuji, K., Isobe, T., Yoshifumi, M. 2009. Controlled Release Of Alpha-Lipoic Acid Through Incorporation Into Natural Polysaccharide-Based Gel Beads. Food Chemistry 115: 483-487.

Lee, W., Ku, SK., Bae, JS. 2012. Barrier protective effects of rutin in LPSinduced inflammation in vitro and in vivo. Food and Chemical Toxicology 50: $3048-3055$.

Li, S., Yuanyuan, G., Ping, Z., Tingshu, Y. 2013. Role of Ox-LDL/LOX-1/NF- $\mathrm{B}$ signaling pathway in regulation of atherosclerotic plaque growth by testosterone in male rabbits. Vascular Pharmacology 59: 131-137.

Shay, P., Régis, M., Eric, S., Anthony, S., Tory M., Hagen. 2010. Alpha-lipoic acid as a dietary supplement: Molecular mechanisms and therapeutic potential. Biochimica et Biophysica Acta 1790: 1149-1160.

Wang, X., Yu, Y., Ji, L., Liang, X., Zhang, T., Hai, C. 2011. Alpha-Lipoic Acid Protects Against Myocardial Ischemia/Reperfusion Injury Via Multiple Target Effects. Food and Chemical Toxicology. 49: 2750-2757.

WHO. 2011. Noncommunicable Diseases Country Profiles. WHO Library Cataloguing-in-Publication Data. ISBN $978924150228 \quad 3$ C) World Health Organization 2011.

Xu, Y., Kong, X., Zhoua, H., Zhang, X., Liu, J., Yana, J., Xie, H., Xie, Y. 2013. 
PHARMACONJurnal Ilmiah Farmasi - UNSRAT Vol. 9 No. 1 FEBRUARI 2020 ISSN 2302 - 2493

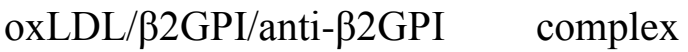 induced macrophage differentiation to foam cell involving TLR4/NF-kappa B signal transduction pathway. Thrombosis Research 134: 384-392

Zhao, W., Ma, G., Chen, X. 2014. Lipopolysaccharide Induced LOX-1 Expression via TLR4/MyD88/ROS Activated p38MAPK-NF- $\kappa$ B Pathway. Vascular Pharmacology. 63: 162-172 